\title{
Transnational Holocaust Memory, Digital Culture and the End of Reception Studies
}

\author{
Wulf Kansteiner
}

Holocaust memory and memory studies have always been intertwined. In the 2oth century, Holocaust memory advocates and memory studies scholars shared enthusiasm for politics of regret. In the 21st century, they have to share the blame for allegedly fostering Euro-centrism. ${ }^{1}$ All along the way, the conceptual infrastructure of memory studies developed in large measure through scholarly analyses of emerging memories of the Final Solution. That applies first and foremost to concepts of transnational memory which are almost synonymous with Holocaust memory scholarship. ${ }^{2}$ The marriage made both empirical and ethical sense. Holocaust memory was one of the first fully-fledged transnational collective memories traveling around the Northern hemisphere in the form of attractive imagetexts and uniting publics from different countries in appreciation of similar media events. Moreover, Holocaust memory seemed to be an unequivocal mark of political progress, helping a formerly divided continent traverse the great distance from the depths of the world wars to peaceful and prosperous cooperation in the European Union. The transformation was particularly pronounced and tangible in (West) Germany where significant segments of society recalled the crimes of the Nazi period with sincere remorse and acknowledged the suffering of their former victims under the sign of Holocaust memory. ${ }^{3}$ Given such promising realignments, memory scholars quickly connected the dots. Negative heritage in the form of Holocaust memory appeared to be the perfect moral conduit for advancing a human rights agenda in the age of globalization. After a phase of catastrophic

1 Dirk Moses, “Conceptual Blockages and Definitional Dilemmas in the 'Racial Century:' Genocides of Indigenous Peoples and the Genocide," in Colonialism and Genocide, edited by Dirk Moses and Dan Stone (Routledge: New York, 2007), 148-180.

2 Chiara De Cesari and Ann Rigney, "Introduction," in Transnational Memory: Circulation, Articulation, Scales, edited by Chiara De Cesari and Ann Rigney (Berlin: DeGryuter, 2014), 1-25, 10.

3 Jeffrey Olick, The Sins of the Fathers: Germany, Memory, Method (Chicago: University of Chicago Press, 2016). 
self-destruction in the age of nationalism, the Western world seemed to have hit upon a formula for effective moral education based on natural affinities between the economic-political dynamics of late modernity and the similarly growth-oriented forces of mediatized self-reflexive memory culture. ${ }^{4}$ Consequently, many scholars in the burgeoning field of memory studies assumed that the blessings of Holocaust memory could work wonders in a wide range of settings, including in societies with little geographical or historical proximity to the events of the Final Solution. ${ }^{5}$

In the meantime, we have left behind the optimism of cosmopolitan memory. It has become clear that a given society can cherish Holocaust memory and yet intentionally engage in serious human rights violation. Or, depending on one's interpretation of US, Israeli and EU foreign policy, one could come to the even more depressing conclusion that the presence of a mature Holocaust memory regime enhances the risk for the illegitimate and unethical use of military force. So on second look it seems that the moral effects of official Holocaust memory are a rather complicated issue. First of all, official, statesponsored Holocaust culture might increasingly look the same all across the West but has nevertheless had different memory effects in different national and institutional settings. In matters of Holocaust remembrance cultural homogeneity hides a considerable degree of political diversity. Second, official Holocaust memory only seems to have become an important moral force in societies in which transcultural Holocaust narratives and iconography became a key reference point of national self-identification. In some national settings official Holocaust memory thus temporarily assumed a truly self-critical profile; in others settings it has always been a force of national self-promotion. Third, as official Holocaust memory has become a more clearly transnationally and transculturally constituted collective memory, upheld by transnational institutions and transnational carrier groups such as academics and memory professionals, it seems to have lost some of its ability to serve as truly self-critical moral compass. Finally, while these emplotments of the history of Holocaust culture appear perfectly plausible they are difficult to prove because we have only limited insights in the reception of Holocaust culture over the course of the last four decades.

There are good reasons to assume, for instance, that the invention of popular Holocaust memory in Germany in the 1970s and 1980s, accomplished with

4 Daniel Levy and Nathan Sznaider, The Holocaust and Memory in the Global Age (Philadelphia: Temple University Press, 20o6); see also Amos Goldberg and Haim Hazan (eds.), Marking Evil: Holocaust Memory in the Global Age (New York: Berghahn, 2015).

5 Jeffrey Alexander, "The Social Construction of Moral Universals," in Alexander et al., Remembering the Holocaust: A Debate (Oxford: Oxford University Press, 2009), 3-101. 
considerable trans-Atlantic input from Hollywood, has temporarily had truly self-critical effects in (West) German society. In fact, one might speak here of an example of cultural trauma, i.e., a mediated collective agreement among significant cross sections of society perceiving a lack of collective identity and purpose caused by the realization of the extraordinary crimes committed by Germans during World War II. ${ }^{6}$ In the meantime, that productive sense of empathic unsettlement has subsided. ${ }^{7}$ After a pivot point during the 1990s, unified Germany has regained a robust sense of pride anchored, for instance, in a widely shared belief in Germany's extraordinary accomplishments in the arena of memory politics. ${ }^{8}$ One should not be surprised by this turn of events, crafted once again with generous help from abroad. Societies seem to strive (naturally, one is tempted to say) to devise and re-tool strategies of collective remembrance for the purpose of collective self-praise. The resulting memory comfort zones might invoke stories of heroism, eternal victimization or memory championship but, social, political and psychological contexts permitting, they tend to alleviate rather than exacerbate feelings of unsettlement and trauma.

Despite a general yearning for uplifting memories, self-critical strategies of collective remembrance can and have travelled widely. The combination of indigenous self-critical inquiries into shameful wwII collaboration and the export of the (West) German model of Holocaust education has resulted in phases of more or less self-critical memory in many Western European countries, including the Netherlands, France, Belgium, Norway and Austria. ${ }^{9}$ But as the transnationalization of Holocaust memory has transformed the Final Solution from a national into a transnational historical event and the task of remembrance from a German into a European obligation, culminating in the adoption of Holocaust memory as a quasi-official foundational EU memory and civic religion in Stockholm in 2000, Holocaust memory has lost a great deal of the self-critical edge it possessed in some settings. ${ }^{10}$ The new perception of the Holocaust as a European human rights catastrophe with lots of blame to go around ended decades of German exceptionalism. With the German model

6 On the concept of Cultural Trauma see Jeffrey Alexander, Cultural Trauma: A Social Theory (Cambridge: Polity, 2012).

7 For the concept of empathic unsettlement see Dominick LaCapra, Writing History, Writing Trauma (Baltimore: Johns Hopkins University Press, 2014).

8 See for example Norbert Frei's polemic comments about the student movement's collective memory in Germany, "Zum erneuten Dienstjubiläum der 'Achtundsechziger': Generation Sündenstolz," Neue Züricher Zeitung, 3/8/2008. Roni Stauber (ed.), Collaboration with the Nazis: Public Discourse after the Holocaust (New York: Routledge, 2011).

Aline Sierp, History, Memory, and Trans-European Identity: Unifying Divisions (New York: Routledge, 2014), 123-136. 
of memory management embraced across the continent and historical responsibility spread on many shoulders, unified Germany assumed a leadership position commensurate with its political and economic heft. And once again Europe followed Germany's lead, turning self-critical into merely self-reflexive memory and, in the process, shifting focus from acknowledging past crimes and making amends to exhibiting and celebrating Europe's extraordinary willingness of acknowledging past crimes and making amends. ${ }^{11}$

Therefore, one should also not be surprised that institutionalized Holocaust memory never assumed much of a self-critical edge in communities spared the onus of perpetrator status or legacies of collaboration, as for example Israel and the Us. When survivors of the Final Solution for the first time stepped into the public limelight, in the context of the Eichmann trial in Israel, the full extent of their suffering and lack of recognition of that suffering after wwII caused a temporary sense of self-doubt in Israeli society. But even in a diverse memory culture such as Israel's, official Holocaust memory has been consistently and skilfully deployed as a political asset justifying the use of force and the violation of human rights. ${ }^{12}$ There is no indication, for example, that the civil religion of Holocaust memory enshrined at Yad Vashem helped Israelis understand the historical injustice of the Nakba and embrace policies of regret and restitution. ${ }^{13}$ In the same vein, the many public institutions of Holocaust memory in the us have complemented popular culture's happy memories of WWII as the good war, rendering it all the more difficult for mainstream us society to imagine its soldiers in the role of perpetrators despite ample evidence to the contrary. ${ }^{14}$ Celebrating the liberators of World War II seems to stand in the way of coming to terms with us war crimes past and present. In this context, one may also wonder about how precisely Holocaust memory and the memory of slavery intersect in us politics and culture. Has the rise of popular Holocaust memory, from the broadcast of the TV series Holocaust in 1978 to the inauguration of the Holocaust Memorial Museum (USHMM) in 1993, delayed

11 Bill Niven, "German Victimhood Discourse in Comparative Perspective," in Dynamics of Memory and Identity in Contemporary Europe, edited by Eric Langenbacher, Bill Niven and Ruth Wittlinger (New York: Berghahn, 2012), 180-194, 185.

12 Idith Zertal, Israel's Holocaust and the Politics of Nationhood (Cambridge: Cambridge University Press, 2005).

13 Ronit Lentin, Co-Memory and Melancholia: Israelis Memorialising the Palestinian Nakba (Oxford: Oxford University Press, 2010), 28; see also Jennifer Hansen-Glucklich, Holocaust Memory Reframed: Museums and the Challenges of Representation (New Brunswick: Rutgers University Press, 2014).

14 John Bodnar, The "Good War" in American Memory (Baltimore: Johns Hopkins University Press, 2010), 221. 
the official recognition for the traumas of slavery? After all, the dark heritage of slavery only attained a permanent memory presence on the National Mall in Washington D.C. when the National African History and Culture Museum (NAHCM) opened in September 2016. ${ }^{15}$ Or, was the presence of Holocaust memory, setting a precedent for negative remembrance, an indispensable precondition for the delayed development of an increasingly self-critical official memory of slavery? Put differently, was there never an option for a direct way from the media event Roots to NAHCM, without the detour through Holocaust and USHMM?

The comparison of Holocaust and slavery memories in the US illustrates the difference between self-reflexive and self-critical sites of memory. Collective memories are self-reflexive as a matter of course; they tend to explicitly address historical events from a given collective's real or imagined past and imbed them in patterns of interpretation integrating past, present and future into meaningful story lines. The stories come in different flavours and hybrids. They might feature largely positively connoted events integrated into positive narrative trajectories, as for instance the events of the American revolution as part of an uplifting history of Us democracy; ${ }^{16}$ negatively connoted events integrated into positive narrative trajectories, for example traditional recitations of Polish suffering as part of gratifying invocations of Polish resilience; ${ }^{17}$ or negatively connoted events integrated into stories expressing collective feelings of doubt and regret as during the first decade of Holocaust culture in West Germany. The last story type is most likely to produce self-critical sites of memory, posing probing questions about past failures and their ongoing relevance in an atmosphere of relative collective insecurity. ${ }^{18}$ Phases of cultural trauma offer opportunities to inquire into the causes of past crimes and address the all-important questions of if and how a given collective can prevent its members from becoming perpetrators (again). Self-critical memory deals with one's own crimes, not the crimes of others and targets the centre of an ingroup's symbolic sense of self. Self-critical memory pursues the question of what

15 Tonya Bolden, How to Build a Museum: Smithsonian's National Museum of African American History and Culture (New York: Viking, 2016); for the memory of slavery in the Us see also Ron Eyerman, Cultural Trauma: Slavery and the Formation of African American Identity (Cambridge: Cambridge University Press, 2001).

16 Janice Hume, Popular Memory and the American Revolution (New York: Routledge, 2014).

17 Ewa Ochman, Post-Communist Poland: Contested Pasts and Future Identities (New York: Routledge, 2013).

18 See in this context Jörn Rüsen's typology of historical narration and especially his concept of critical narration, Rüsen, Historik: Theorie der Geschichtswissenschaft (Cologne: Böhlau, 2013), 213. 
illegitimate or immoral acts of violence are implicated in a group's cherished accomplishments. Consequently, self-critical memories thrive along vectors of passionate identification raising the intriguing question to what extent people around the globe feel themselves passionately involved in transnational concepts and practices of collective belonging. Transnational political institutions often appear to elicit at best lukewarm responses from its constituencies and therefore do not constitute promising arenas of self-critical memory politics. In this sense, it is, for instance, unrealistic to expect that a memory institution such as the House of European History will elicit powerful feelings about Europeaness, let alone be able to channel these feelings into decidedly self-critical memory trajectories. ${ }^{19}$ In fact, it might be altogether unrealistic to expect that the kind of media that ushered in Holocaust memory 35 years ago, i.e., television, film, museums and memorials, could still provoke passionate feelings in audiences steeped in interactive digital culture and living at a point in time when the remembrance of the Final Solution transitions from the dynamic realm of communicative memory to the settled realm of cultural memory. All in all, the deck is clearly stacked against Holocaust memory serving (again) any time soon as a truly self-critical site of memory. Generational, media historical and transnational dynamics of memory culture are likely to relegate Holocaust culture-as-we-know-it to the dustbin of cultural hagiography.

If Holocaust memory can be resurrected as an emotionally and politically relevant fixture of future memory culture it would have to be in the guise of immersive, simulative and possibly also counterfactual digital memory. Gaming culture, social media networks and digitally empowered academic exchange are the kind of cultural environments where Holocaust culture might get a second lease on life as a transnationally shared, passionately pursued and possibly also self-critically inflected memory practice. A selective glance at digital Holocaust culture suggests, however, that the new media of collective remembrance are often embedded in traditional power structures and that the more innovative environments raise intriguing questions about the thematic boundaries and collective subject positions of Holocaust memory. While Holocaust allusions abound in cyberspace and established institutions of Holocaust memory make ample use of digital technologies, Holocaust memory has simply not yet arrived in the digital age - if we identify as one of the key attractions of digital culture its ability to offer users the experience of captivating historical narrative worlds combined with the compelling illusion of being able to inflect the narrative trajectories of these worlds according to their own

19 Wolfram Kaiser, "Limits of Cultural Engineering: Actors and Narratives in the European Parliament's House of European History Project," Journal of Common Market Studies 55/3 (2017), 518-534. 
aesthetic predilections. Put differently, digitized Holocaust culture features a great deal more conservative remediation of analogue and electronic media contents, formats and communication patterns than one would expect or like to see given the fact that other segments of contemporary historical culture offer fully fledged immersive and interactive historical worlds. Moreover, in light of Holocaust culture's refusal to go fully interactive and simulative, it is difficult to imagine which groups might passionately embrace Holocaust memory as a key element of their collective sense of self let alone turn it into a site of rigorous self-criticism.

\section{Gaming the Holocaust Paradigm?}

The ritual has been played out on a number of occasions in recent years: somebody greedily, provocatively or courageously develops a Holocaust themed video game and is promptly pressured to abandon the project. In 2010, a group of Wolfenstein ${ }_{3} D$ modders, led by a young Israeli, developed a technologically crude Auschwitz revenge game loosely based on the 1944 uprising of members of the Auschwitz Sonderkommando who succeeded in killing three ss-guards and setting fire to one crematorium. ${ }^{20}$ The game that the group worked on for over three years featured Nazi violence in the camp and then turned the tables on the torturers and had players in the role of Jewish inmates go on a killing spree of the Nazi camp personnel from a first-person-shooter perspective. ${ }^{21}$ The response came quickly after the release of a pilot. ${ }^{22}$ Representatives of the Wiesenthal Center and the Anti-Defamation League rejected the project because 'the Holocaust should be off-limits for video games'. ${ }^{23}$ Citing negative media attention and attendant emotional stress, the group cancelled the game

2o The uprising has been subject to various retellings; see the measured words in Nicholas Chare/Dominic Williams, Matters of Testimony: Interpreting the Scrolls at Auschwitz (New York: Berghahn, 2016), 6-7; and compare, for instance, to Leni Yahil, The Holocaust (New York: Oxford UP, 1990), 486.

21 Michael McWherto, "Concentration Camp Game Was Meant To Be Fun," Kotaku, 10 December, 2010, http://kotaku.com/5711317/concentration-camp-game-was-meant-tobe-fun. Accessed 21 October, 2016.

22 See the pilot and additional screen shots: "Sonderkommando Revolt Wolfenstein ${ }_{3} \mathrm{D}$ mod," last updated 13 December, 2010, http://www.moddb.com/mods/sonderkommandorevolt. Accessed 21 October, 2016.

23 Brian Crecente, “Anti-Defamation League Slams ‘Fun' Holocaust Video Game as Horrific and Inappropriate," Kotaku, 11 December, 2010, http://kotaku.com/5712163/anti-defamation-league-slams-fun-holocaust-video-game-as-horrific-and-inappropriate, Accessed 21 October, 2016. 
weeks before its scheduled release date. ${ }^{24}$ Apparently, violent counterfactual Jewish revenge fantasies are intriguing and prize-worthy on the big screen in, for instance, Inglourious Bastards, but unacceptable in the allegedly low-brow cultural environment of video game coding and modding. ${ }^{25}$

A New York City indie programmer has had a similar experience with a very different kind of video game project. Since 2008, Luc Bernard has worked on Imagination is the only Escape, which is set in Nazi-occupied Paris and depicts the suffering of Jews from the perspective of a young Jewish boy. The game blends history and fantasy in an effort to produce visually and narratively sophisticated historical fiction about the Shoah and has received much advance praise from game critics. Nevertheless, Bernard could not find distribution venues and most recently also failed in his efforts to raise capital through a crowdsourcing initiative. ${ }^{26}$ For a video game designer it is clearly a bad career move to invest creative efforts and many months at the screen in crafting a Holocaust-themed virtual game environment. The situation is vaguely reminiscent of Holocaust scholarship in the 196os when the few scholars trying to write the history of the Final Solution struggled with similar prejudices. ${ }^{27}$ Today, even big players in the huge and influential video game industry are only carefully inching closer to the taboo subject matter of Holocaust gaming. In this vein, the powerful Wolfenstein franchise, now owned by Bethesda Softworks, stepped into a fictitious Nazi concentration camp in its successful 2014 release of Wolfenstein: The New Order. In the counterfactual game set in the 196os after the Nazis have won wwII, Wolfenstein hero Blazkowicz infiltrates a Nazi camp to liberate a brilliant Jewish scientist. The short episode features provocative images including a female camp commander holding a

24 Riva Gold, “Designers Pull Plug on Auschwitz Death Camp RevoltVideo Game," Haartz.com, 26 December, 2010; http://www.haaretz.com/jewish/designers-pull-plug-on-auschwitzdeath-camp-revolt-video-game-1.333022. Accessed 21 October, 2016.

25 In 2009 the ADL, for instance, praised Inglourious Basterds as "an allegory about good and evil and the no-holds barred efforts to defeat the evil personified by Hitler, his henchmen and his Nazi regime. If only it were true," "ADL Statement on Quentin Tarrantino's 'Inglourious Basterds,", archive adl.org, 18 August, 2009, http://archive.adl.org/presrele/ holna_52/5585_52.html\#.V852dBRoU6U. Accessed 21 October, 2016; for a scholarly assessments of the movie's transgressive accomplishments see Robert Dassanowsky (ed.), Quentin Tarantino's Inglourious Basterds: A Manipulation of Metacinema (New York: Continuum, 2012).

26 "Imagination Is The Only Escape," Indiegogo.com, https://www.indiegogo.com/projects/ imagination-is-the-only-escape\#/. Accessed 21 October, 2016. 
baby upside down by its leg, whip at the ready, before the 'camera' swiftly cuts to another scene. ${ }^{28}$

Critics and gamers have identified a number of reasons for the Holocaust gaming taboo. Mainstream games with attractive graphics are expensive and therefore game developers tend to copy and fine-tune previously successful formats rather than launching radically new aesthetics and content matter. Moreover, a lot of fast-paced, action-oriented video game violence thrives on simple plot structures that seem to preclude the kind of complex narrative explanations scholars use to account for events like the Final Solution. Finally, the gaming industry lacks auteur figures such as Lanzmann, Spielberg or Tarantino who can more easily transgress limits of historical taste. Consequently, as Jeff Hayton has pointed out, 'medium, genre, and economics all work as inhibiting factors steering video games away from a sustained engagement with Nazism and the Holocaust. ${ }^{29}$ Last but not least, some of the key players of the Holocaust memory establishment cannot imagine how they could successfully transfer their didactic and political mission into simulative and interactive ludic digital environments and have therefore concluded that video games and their brand of genocide/human rights education are simply incompatible with each other.

Reservations about the compatibility of the medium video game with serious historical subject matter are not limited to Holocaust themes; they also exist with regard to other topics including $9 / 11^{30}$ and slavery. ${ }^{31}$ At the same time, video games have conquered the historical imagination of many players

28 Plygon, "The New Order shows you the horror of concentration camps from the first person," YouTube, 19 May 2014, https://www.youtube.com/watch?v = DbQ3 H6lEWDE. Accessed 21 October, 2016.

29 Jeff Hayton, "Beyond Good and Evil: Nazis and the Supernatural in Video Games," in Monica Black/Eric Kurlander (eds.), Revisiting the "Nazi Occult:" Histories, Realities, Legacies (Rochester: Camden House: 2015), 248-269.

30 Consider for instance the $9 / 11$ virtual reality reenactment $08: 46$ based on a student project: DarkWolfLetsPlay, "08:46/9/11 Terrorist Attack Oculus Rift Game," youtube, 19 October, 2015, https://www.youtube.com/watch?v = vd2_j8dsOsM. Accessed 21 October, 2016; and see the helpful review by Adi Robertson, "The virtual reality $9 / 11$ experience is bad, but not for the reasons you'd expect," The Verge, 30 October, 2015, http://www.theverge .com/2015/10/30/964279o/virtual-reality-9-11-experience-empathy. Accessed 21 October, 2016.

31 "Slave Trade Video Game Edited After Backlash," Huffington post, 3 September, 2015, http://www.huffingtonpost.com/entry/slave-trade-game-edited-following-backlash _us_55e848gbe4bob7a9633bdc73. Accessed 21 October, 2015. 
as games with historical themes proliferate.$^{32}$ Moreover, as a result of the development of serious gaming during the last 15 years, video games now play a decisive role in government and corporate training, education, health care and public policy. ${ }^{33}$ The gaming community is very aware of this disconnect and some game critics have already concluded that the status quo in digital Holocaust memory is untenable. Given the cultural prominence of video games in general and games with historical themes in particular it amounts to a strange case of Holocaust denial in reverse that no sophisticated game about the topic yet exists. ${ }^{34}$ That way, the field is left wide open to dubious right-wing concoctions such as KZ Manager ${ }^{35}$ and, even more importantly, the medium's extraordinary didactic potential remains untapped. As prominent history game designer Brenda Romero has emphasized, due to their interactive nature 'games convey complicity like no other medium can. ${ }^{36}$ Therefore, they

32 Matthew Kappell/Andrew Elliott (eds.), Playing with the Past:Digital Games and the Simulation of History (New York: Bloomsbury, 2014); see also Daniel Kline (ed.), Digital Gaming Re-imagines the Middle Ages (London: Routledge 2014); Chris Kempshall, The First World War in Computer Games (New York: Palgrave Macmillian, 2014); Tobias Winnerling and Florian Kerschbaumer (eds.), Early Modernity and Video Games (Newcastle: Cambridge Scholars, 2014); and Nina Huntemann and Matthew Payne (eds.), Joystick Soldiers: The Politics of Play in Military Video Games (New York: Routledge, 2010).

33 For a definition and historical overview of serious gaming see Christian Loh, Yanyan Sheng and Dirk Ilfenthaler, "Serious Games Analytics: Theoretical Framework," in Serious Games Analytics: Methodologies for Performance Measurement, Assessment, and Improvement, edited by Christian S. Loh, Yanyan Sheng and Dirk Ifenthaler (Cham: Springer, 2015), 3-29; see also Ralf Dörner, Stefan Göbel, Wolfgang Effelsberg and Josef Wiemers (eds.), Serious Games: Foundations, Concepts and Practice (Cham: Springer, 2016); and Ute Ritterfeld, Michael Cody, Peter Vorderer (eds.), Serious Games: Mechanisms and Effects (New York: Routledge, 2009).

34 Eric Day, "Why We Don't Have a Holocaust Video Game and Why We Desperately Need One," overmental.com, 5 May, 2014, http://overmental.com/content/why-we-dont-havea-holocaust-video-game-and-why-we-desperately-need-one-1303; Luke K, "wwII Games: Where is the Holocaust," Critical Gamer, http://www.criticalgamer.co.uk/2011/01/17/wwiigames-where-is-the-holocaust/. Accessed 21 October, 2016.

35 "KZ Manager," Wikipedia, last updated 21 October, 2016, https://de.wikipedia.org/wiki/ KZ_Manager. Accessed 21 October, 2016.

36 Video game designer Brenda Romero cited in Kaveh Waddell, "A Video Game That Lets You Torture Iraqi Prisoners," theatlantic.com, 1 August, 2016, http://www.theatlantic.com/ technology/archive/2016/o8/a-video-game-that-lets-you-torture-iraqi-prisoners/493379/. Accessed 21 October, 2016. Romero is also the designer of the Holocaust board game Train: Dean Takashi, "Brenda Romero's Train board game will make you ponder," venturebeat. com, 11 May, 2013, http://venturebeat.com/2013/05/11/brenda-romero-train-board-gameholocaust/. Accessed 21 October, 2016; on agency in war games see Pat Harrigan, Matthew 
seem particularly well suited for having gamers intimately explore the experiences and decisions of people living in foreign worlds, including historical narrative worlds. And that intimate knowledge of past actors, may they be victims, perpetrators or bystanders, offers in principle great potential for self-critical memory politics. ${ }^{37}$

The disconnect between a burgeoning historical gaming culture one the one hand and the lack of state-of-the-art Holocaust gaming on the other hand turns video games into an important cultural arena illustrating par excellence Andrew Hoskins' perceptive remarks about the bifurcation of memory culture in an age of digitization. Hoskins identifies a clear division of 'two media/ memory cultures: one formalized, institutionalized, regimented (including online); the other more emergent, confrontational, yet fragmented.' Obviously, both spheres of social memory are closely intertwined and influence each other with the second, more fluid and emergent culture featuring a 'virality that undermines attempts to sanitise history.' 38 For Hoskins the 'immediacy, mobility, flexibility and interactivity' of the new emergent memory is the result of digital hyperconnectivity and particularly pronounced in social networks and file sharing platforms. ${ }^{39}$ Due to its scale and speed the new memory problematizes the relationship between the hitherto stable cultural constructs of 'past' and 'present,' raises anxieties about people's ability to actively shape social memory, and prompts a rush to judgment that disrupts time-tested rituals for containing and forgetting potentially unsettling pasts. The gaming industry, focused on a few particularly profitable markets and dominated by two dozen companies, clearly belongs to the regimented memory culture. In the world of Tencent, Sony and Microsoft, the formal regimes of oblivion and containment, translated into effective processes of self-censorship, are clearly (still) functioning. That raises intriguing questions about digital Holocaust memory in the more fluid and flexible cultural digital contexts of social media and academia.

Kirschenbaum and James Dunnigan (eds.), Zones of Control: Perspectives on Wargaming (Cambridge, MA: MIT Press, 2016).

Adam Chapman, Digital Games as History: How Videogames Represent the Past and Offer Access to Historical Practice (New York: Routledge, 2016).

38 Andrew Hoskins, "The Right to be Forgotten in Post-Scarcity," in, The Ethics of Memory in a Digital Age: Interrogating the Right to be forgotten, edited by Alessia Ghezzi et al. (New York: PalgraveMacmillian, 2014), 50-64, 6o; see also Andrew Hoskins, "Digital Network Memory," in Mediation, Remediation and the Dynamic of Cultural Memory, edited by Astrid Erll and Ann Rigney (Berlin: De Gruyter, 2009), , 91-106. ity: A Critical History of Social Media (Oxford: Oxford University Press, 2013). 
In crafting an identity for itself, the emerging field of digital memory studies follows in the footsteps of other academic disciplines. The proponents of the new field highlight historical developments that cannot be successfully studied by existing scholarly strategies - namely the digital revolution with the instruments of traditional memory studies - and showcase a new set of intellectual tools better suited for the job at hand. ${ }^{40}$ In short, they expose the limits of an established intellectual world and build up a new conceptual infrastructure. On the deconstructive side, all the essential binaries of memory studies become subject to critical review because digital memory requires nothing less than radically 'changing the parameters of the who, what, when, and why of remembering."41 Digital memory no longer evolves along the individualcollective axis. In the post-broadcast era there is no collective to speak of, at least not in the way in which television used to aggregate consumers into audiences through narratives and media events. For the same reason, there are also no clearly identifiable private or public spheres. Participatory digital culture features active individuals constantly posting, editing, liking and linking in pursuit of fluid 'we's' and for the purpose of crafting and exhibiting an attractive self. That job requires an intimate, affective, and symbiotic relationship to digital technology and it is often the machine that dictates the rhythm of communication. ${ }^{42}$ As a result, transhuman entities do the remembering, requiring digital memory studies to leave behind the comfortable human-non-human divide. Since transhuman selves are immersed in expansive networks always in the state of becoming, digital memory also obliterates the conventional differentiation between archives and lived historical culture with serious consequences for the social construction of time. ${ }^{43}$ In fluid networks, audiovisuals of the present rub elbows with audiovisuals from the past, rendering impossible any collectively organized, self-reflexive process of balanced remembering and forgetting. In fact, the very distinction between past and present becomes flexible with transhumans living in an 'extended now,' being unable to leave

40 Karen Worcman and Joanne Garde-Hansen, Social Memory Technology: Theory, Practice, Action (New York: Routledge, 2016), esp. 46-49; Ellen Rutten, Julie Fedor and Vera Zvereva (eds.), Memory, Conflict and New Media: Web Wars in Post-Socialist States (New York: Routledge, 2013); and Joanne Garde-Hansen, Andrew Hoskins and Anna Reading (eds.), Save As ... Digital Memory (Basingstoke: Palgrave Macmillan, 2009).

Andrew Hoskins, "The Restless Past: An Introduction to Digital Memory and Media," in Digital Memory Studies: Media Pasts in Transition, edited by Andrew Hoskins (New York: Routledge, forthcoming).

43 Wolfgang Ernst, Digital Memory and the Archive (Minneapolis: University of Minnesota, 2013). 
behind the ghosts of past humiliations and battling the dystopias of eternal memory, on the one hand, and technological obsolescence and instant memory death, on the other hand. ${ }^{44}$ These fluid, transhuman 'we's' circulate on many planes including transnational and transcultural planes but it is questionable if they also attain enough cultural and political stability to support the arduous process of self-critical remembering. It might take forceful memorial anachronisms such as cosmopolitan memory with its fictions of righteous permanence to launch effective challenges of existing memory regimes. However, for those questions to become relevant Holocaust memory would first have to leave the confines of formalised, institutionalized and regimented digital memory.

\section{Digital Holocaust Education: From the Pedestrian to the Radically Multi-directional}

Given the prominence of the education theme in Holocaust memory it is not surprising that websites of applicable institutions abound with teaching guidelines, online courses and lessons plans adapted to all kinds of curricular contexts. The UK's Holocaust Memorial Day Trust (HM DT) takes, for instance, great pride in 'offering a huge range of resources to educators' although the charity's line-up of teaching tools would be best characterized as numerous rather than diverse. ${ }^{45}$ The overarching theme of Holocaust Memorial Day 2016 was 'Don't stand by' and with that catchy title HMDT invited students and teachers to become creative and craft films, launch social media campaigns or plan a HMD event in support of all sorts of deserving causes, ranging from genocide education to battling sexism and LGBT prejudice. ${ }^{46}$ But previous year's proudly mentioned initiatives and especially the HMDT teaching resources released in support of the 'Don't stand by' theme focus quite narrowly on Holocaust history, encouraging students, for instance, to draw up a character map of a British Holocaust hero, contemplating a number of survivor testimonies or celebrating resistance activities during the Holocaust. ${ }^{47}$ In addition, the teaching

44 Martin Pogacar, Media Archeologies, Micro-Archives and Story-Telling: Re-Presencing the Past (Basingstoke: Palgrave Macmillan, 2016).

45 "For Educators," Holocaust Memorial Day Trust, http://hmd.org.uk/content/for-educators. Accessed 22 October, 2016.

46 "Don't Stand By: Holocaust Memorial Day 2016: What You Can Do," http://hmd.org.uk/ sites/default/files/HMD_files/dont_stand_by_-_final.pdf. Accessed 22 October, 2016.

"Don't Stand By: Holocaust Memorial Day 2016: Lesson Activity: British Heroes of the Holocaust," http://hmd.org.uk/sites/default/files/british_heroes_of_the_holocaust_ resource.pdf. Accessed 22 October, 2016; “HMD 2016: Lesson Plan: Didn't Stand By," 
tools lack interactive depth and ambition, consisting of text PDFs and short incoherent PowerPoint presentations. ${ }^{48}$ HMDT is not an outlier in this context. Most of the established institutions provide teaching resources that are conservative, predictable and uninspiring in content and form. ${ }^{49}$

There are exceptions - some problematic, others truly innovative. Yad Vashem's website features, for instance, an interactive learning environment that describes 'the ghettos during the Holocaust from the children's perspective, and attempts to present this complex experience in a way that is accessible to children. ${ }^{50}$ One might object to the naïve drawings and small scale of the visual learning environment. Yet the platform does present a wealth of visual and historical information in an accessible albeit only rudimentary interactive format. Nevertheless, as a lot of Holocaust products for young audiences, 'Children in the Ghetto' amounts to a strange type of Holocaust denial; the tool repeatedly identifies hunger as a serious problem in the ghettos but refrains from spelling out the consequences or detailing any other problems faced by the ghetto population. ${ }^{51}$ There are excellent reasons for such reticence. As Yad Vashem points out: 'The unsupervised exposure to Holocaust history at a young age may induce trauma in children and could possibly trigger strategies of distanciation and even feelings of resentment towards the topic. 52 The word of warning contains

http://hmd.org.uk/education/hmd-2016-lesson-plan-didnt-stand. Accessed 22 October, 2016; "Life Stories," http://hmd.org.uk/resources/life-stories. Accessed 22 October, 2016.

48 HMDT is currently developing a fully interactive digital teaching tool called HMDT Eteach, but a presentation of the pilot at the BAHS Conference in July 2016 did not reveal a particularly dynamic or innovative platform. Andy Fearn, "HмDт Eteach: A new interactive, multimedia resource to support educators in teaching effectively about the Holocaust and subsequent genocides," BAHS Conference 2016, UCL 7/20/2016.

"Teaching Resources", Holocaust Educational Trust, http://www.het.org.uk/teachingpack. Accessed 22 October, 2016; "The International School for Holocaust Studies: Education Materials," Yad Vashem http://www.yadvashem.org/yv/en/education/index.asp. Accessed 22 October, 2016; "Teacher Resources: Educating Hearts and Minds," Museum of Tolerance, http://www.museumoftolerance.com/site/c.tmL6KfNVLtH/b.5052463/k .AE91/Teacher_Resources.htm. Accessed 22 October, 2016.

"International School for Holocaust Studies: Learning Environments," Yad Vashem, http:// www.yadvashem.org/yv/en/education/learning_environments/index.asp. Accessed 22 October, 2016.

For children's books with similar problems see, for instance, Phoebe Eloise Unterman, Through Eva's Eyes (Kansas City: Landmark, 2009).

$5^{2}$ In October 2016, only the German version of the online game worked. Here the words of warning in the original German: "Die unbeaufsichtigte Beschäftigung mit dem Holocaust in einem jungen Alter kann zu einem Trauma bei Kindern führen, sowie zu Distanziertheit und in manchen Fällen sogar zu einem Gefühl der Feindseligkeit im Zusammenhang 
a strange list of risks implying inadvertently that a sense of resentment towards the topic constitutes as serious a problem as trauma. In this specific case, it is not the laudable search for the new digital teaching tools which constitutes a problem, but the troublesome race to the bottom of the teaching pyramid that seeks to expand the realm of Holocaust memory by enlisting younger and younger captive audiences, for instance by way of digital technology deemed particularly attractive to children. Initiatives such as 'Children in the Ghetto' illustrate that there might indeed be some hard limits of Holocaust memory. Faced with the self-fabricated dilemma of either falsifying history or traumatizing children, silence could be an excellent temporary option.

A second exception is the pathbreaking IWitness initiative of the USC Shoah Foundation. The project is truly remarkable because it hands over editorial power over cultural memory to teachers and high school students, teaching them basic film editing skills and providing them with extensive access to the Shoah Foundation's archive of Holocaust testimonies. The students are furthermore encouraged to enter their films in the yearly IWitness Video competition. The winning entries of 2016 powerfully demonstrate that the students, giving the choice, are ready to leave behind the history of the Holocaust. Time and again, the films take a short clip from survivor testimony out of its historical context and use it as a jumping off point to engage with pressing present-day concerns such as poverty, homelessness, mental illness, animal rights, self-help and human solidarity. ${ }^{53}$ In this way, Holocaust memory becomes a tangential concern subject to powerful multi-directional forces of reframing and forgetting. ${ }^{54}$ The results of the IWitness digital film initiative are not Holocaust memory as we know it and they also do not (yet) amount to fully emergent connective memories. They represent an interesting hybrid: broadcast memories produced by members of a post-broadcast generation. The results indicate that, in an appropriate communicative-didactive setting, handing over interpretive power to transhuman memory amateurs should give less cause for ethical concern than, for example, encouraging designated memory experts to craft Holocaust curricula for young children.

mit dem Thema," see “Die Internetseite 'Kinder im Ghetto:' Kommentare für Lehrer," Yad Vashem, http://ghetto.galim.org.il/ger/about/lessons.html. Accessed 22 October, 2016.

"IWitness Video Challenge: Top Videos by Groups - 2016," University of Southern California, http://iwitness.usc.edu/SFI/IWitnessChallenge/Winners.aspx?y = 2016. Accessed 22 October, 2016.

54 On the concept of multi-directional memory see Michael Rothberg, Multidirectional Memory: Remembering the Holocaust in the Age of Decolonization (Stanford: Stanford UP, 2009). 
At the same time, the Shoah Foundation has pursued ambitious transhuman experiments designed to retain power of interpretation for the institution. For a number of years, the most digitally advanced institution of Holocaust memory has been tinkering with Holocaust holograms. The developers combine visual testimony of survivors of the Shoah, taped over the last few decades, with highly sophisticated computer software. They hope to be able to stage captivating encounters between tomorrow's school children and the holograms of yesterday's survivors in which the ghosts from the past answer the children's questions in an interactive setting and an atmosphere of pious, intergenerational respect. ${ }^{55}$ The holograms of survivors are very good at mastering the past; in simulated conversation they seemingly spontaneously provide the details of their family histories, camp ordeals, survival strategies and postwar lives. But they cannot handle the present; don't ask them what they had for breakfast today. At some point during the communicative process, the ingenious hybrid of dialogical questions and monological answers breaks down. The holograms are a fantastic attempt to stem the tide of history and decelerate the historicization of Holocaust memory. Their creators certainly understand the stakes of Holocaust memory in today's rapidly changing demographic and media environment. The culturally constructed aura of the Holocaust survivors has been a crucial component of Holocaust education in the past decades. ${ }^{56}$ For the future of Holocaust memory it is important that that aura gets a second lease on life or is replaced by a similarly attractive memorial focus. The holograms embody the insight that Holocaust survivors as we encountered them on TV or in video testimonies represent a media figure which should, in principle, be able to survive the biological deaths of the actual survivors.

It will be interesting to follow the careers of the holograms. If their developers and the protagonists of digital memory studies read contemporary culture correctly the holograms could become exoskeletal media stars. But it is also possible that the figure of the survivor, in its new digital disguise, does not attain the same media success that its analogue predecessor enjoyed on the TV

55 For a video demonstration see itc Graphics Lab's "New Dimension in Testimony USC ICT and SFI Classroom Concept," 8 February, 2013, http://www.youtube.com/ watch? = AnF63otCiEk. Accessed 24 October, 2016; see also Sophia Stuart, "How Natural Language Tech, Holograms Are Preserving Holocaust Testimony," pcmag.com, 8 April, 2016, http://www.pcmag.com/article/343452/how-natural-language-tech-holograms-arepreserving-holocaus. Accessed 24 October, 2016.

$5^{6}$ Jeffrey Shandler, While America Watches: Televising the Holocaust (Oxford: Oxford University Press, 1999); Oren Meyers, Eyal Zandberg and Motti Neiger (eds.), Communicating Awe: Media Memory and Holocaust Commemoration (New York: Palgrave Macmillian, 2014); and, more critically, Ann Rothe, Popular Trauma Culture: Selling the Pain of Others (New Brunswick, 2011). 
screens over several decades. In the past, the aura of the survivors depended on a specific media effect. The viewers had to be able to entertain the illusion that they could meet the survivors in their everyday lives and talk to them about the extraordinary past. Through small, seemingly insignificant markers such as clothing, speech, body language, lighting and background, the coverage conveyed a powerful sense of historical simultaneity. The words and images on the screen created an atmosphere of co-presence, placing survivor and viewer in the same time frame and social universe. ${ }^{57}$ But the holograms are no longer aesthetically and narratively embedded in the present-day social context of the observer. Despite their technological sophistication, the holograms cannot be effectively and continuously brought up to date; they might always carry small, yet pervasive markers of historical non-simultaneity. Therefore, they are perhaps unable to fulfil the shuttling-service between past and present that the mediated survivors of the TV coverage of the 1980s and 1990s accomplished on a regular basis. In the era of analogue and electronic media, nobody managed to invent media aesthetics that could prevent their own historicization, but perhaps that rule no longer applies in an age of hyperconnectivity. Either way, the holograms only amount to a clever simulation of true digital interactivity. Unless the holograms are released into the wild online, its 'dialogue' partners cannot challenge the holograms' memory, the conceptual or narrative frame of Holocaust remembrance or the emotional frame of intergenerational piety. In an institutional communicative triangle comprising tomorrow's school children, the digital ghosts of Holocaust survivors, as well as heritage professionals and software developers, power is concentrated in the hands of the representatives of the Shoah Foundation although it is difficult to determine if today's and tomorrow's school children also perceive of the distribution of power in this way.

\section{Facebook Broadcasting: 'Never again without Memory'}

The tension between regimented and emergent digital memories, i.e., between institutional authorial control and the consumers' desire to engage with history on their own terms and according to their own narrative/aesthetic preferences is even more pronounced on the social media front. In August 2016, the USHMM took the Olympic Games in Brazil as an opportunity to enlighten its

57 Wulf Kansteiner, "Macht, Authentizität und die Verlockungen der Normalität: Aufstieg und Abschied der NS-Zeitzeugen in den Geschichtsdokumentationen des ZDF," in Die Geburt der Zeitzeugen nach 1945, edited by Martin Sabrow and Norbert Frei (Göttingen: Wallstein, 2013), 320-353. 
150,000 followers via Facebook about the 1936 Berlin Olympics, reporting in a series of 15 entries about the partial exclusion of Jews and the denigration of black athletes by Nazi authorities. The posts generally elicited hundreds of likes, several dozen shares and a handful of comments each. They represent a routine flow of Facebook entries primarily based on information readily available in the Usнmm's Holocaust Encyclopedia and photo archives. Occasionally, the coverage was interrupted by more current concerns. The museum marked for instance 'the second anniversary of the beginning of the Islamic State's genocide of the Yezidi' (8/2) with the help of a poster of the Free Yezidi Foundation emphasizing that the UsHMM staff had already assembled a report on the matter. ${ }^{58}$ The PR tactic of trying to fit an ongoing genocide into an anniversary obsessed memory culture in order to have somebody pay attention to the Yezidi's plight did not trigger the desired reaction. Within three weeks the post elicited an underwhelming response of a total of 117 likes/sads/ angries, 62 shares, and only one comment, whose author referred to the Nazi precedent and pointed out 'that reports are great for documentation and later trial but ... overwhelming force and unconditional surrender are the only things that stop genocide. 59

The USHMM PR officers had more luck with an entry on 11 August, deploring the suffering of civilians in the besieged city of Aleppo, Syria. Carefully chosen phrasing ('these crimes could amount to genocide') were combined with a well edited, heart-wrenching video clip showing pictures of a hospitalized five-year old boy, a victim of a Syrian government attack, who later died of his injuries. ${ }^{60}$ The clip was viewed 158,525 times and with 1,105 shares proved to be the most successful entry of the month. The 145 lively comments are particularly intriguing, documenting multi-directional memory in action as commentators addressed the important questions of who is to be blamed for and what is to be done about the war crimes in Syria. Many users voiced massive frustration with government variously highlighting the failure of local and regional

58 In June 2016 the UN officially determined that Isis is committing genocide against the Yazidis: "UN Commission of Inquiry on Syria: ISIS is committing genocide against the Yazidis," United Nations Human Rights Office of the High Commissioner, 16 June, 2016, http://www.ohchr.org/en/NewsEvents/Pages/DisplayNews.aspx?NewsID = 20113\&LangID = E. Accessed 22 October, 2016; see also "UN: Yezidi 'genocide has occurred and is ongoing," Rudaw, 16 June, 2016, http://rudaw.net/english/middleeast/16o62016. Accessed 22 October, 2016.

59 USHмm's Facebook page, 2 August, 2016, https://www.facebook.com/holocaustmuseum/. Accessed 23 August, 2016.

6o USHmM's Facebook page, 11 August, 2016, https://www.facebook.com/holocaustmuseum/. Accessed 23 August, 2016. 
leadership in the Middle East, the flawed foreign policy of the us, and, more specifically, the particular responsibility of the Obama administration. The comments, overwhelmingly coming from the Us, run the gamut from rigorous self-criticism ('The us is very much responsible for this' ${ }^{61}$ ) to determined isolationism ('No sympathy!! America has our own problems'62). In this context, commentators also discussed immigration, offered prayers and time and again deplored the suffering of innocent children. Some comments are politically incorrect ('Ya lets replace another raghead countries leader it worked so good in iraq and libya ... idiots who gives a fuc they have been slaughtering each other for thousands of years' 63 ); others are difficult to interpret even when looking at the specific context of the post ('It's time for a Muslim genocide, emoij'64). It was a lively, at times contentious discussion containing hardly any comments dealing with Holocaust history.

The successful entry about Syria raises interesting questions about the relevance of historical precedent in political communication and the role of Holocaust institutions in shaping communicative memory. The subscribers of the Usнmm feed and their Facebook friends probably share a relatively strong interest in history, but the explicit historical references included in the comments deal with the very recent past; only two commentators create analogies to WwII history. The Nazi past does not appear to resonate strongly with USHMM followers trying to make sense of the war in Syria. Moreover and more important for our purposes, having successfully triggered a debate, the USHMM stays completely silent during subsequent discussions. Throughout the month of August 2016, USHMM only once responded to a commentator providing specific historical information. Otherwise it stayed above the Facebook flow and fray even when specifically prompted by its Facebook friends to respond or take a position. ${ }^{65}$ That passivity seems to reflect the general policy of the USHMM and other Holocaust institutions whose staff members prefer

61 Dennis Howard on Ushmm's Facebook page, 20 August, 2016, https://www.facebook .com/holocaustmuseum/. Accessed 23 August, 2016.

62 Overwatch Blizzard on Us Hмm's Facebook page, 22 August, 2016, https://www.facebook .com/holocaustmuseum/. Accessed 23 August, 2016.

63 Dan Gunner on usнmм's Facebook page, 20 August, 2016, https://www.facebook.com/ holocaustmuseum/. Accessed 23 August, 2016.

64 Dylan H. Brown on ushmm's Facebook page, 21 August, 2016, https://www.facebook.com/ holocaustmuseum/. Accessed 23 August, 2016.

65 Ron Van Cleef: "Yes, this is terrible, but I am curious if the usнmm has condemned the us bombings of civilians in Syria, Afghanistan and other places?” on ushmm's Facebook page, 11 August, 2016, https://www.facebook.com/holocaustmuseum/. Accessed 23 August, 2016. 
one-directional communication, 'broadcasting' a carefully shaped, widely acceptable message via social media, but refusing to engage further and bring their considerable expertise to bear on the difficult moral questions of how to develop an appropriate communicative memory of war crimes and what political consequences to draw from that memory. The users, for that matter, appear to expect and accept this miscommunication, perhaps because they are not looking at institutions like the UsHmM for historical and political guidance. Apparently, they simply like to be part of the group and share its values. As one user puts it: 'amazing 1099 shares wonderful.'66 For many 'subscribers,' the USHMM Facebook page seems to be a cyberspace address where they can hang out with peers, pursue their genocide memory interests by adding a thoughtful facet to their virtual selves, and then return to their comfortable lives.

Put into more abstract terms, the Facebook feed of the Us нмм is the place where the carefully balanced, politically correct cosmopolitan Holocaust memory comes in direct, dysfunctional contact with the kinds of antagonistic and agonistic memories that pervade everyday life. ${ }^{67}$ In response to the Aleppo post, some subscribers yelled at each other in an antagonistic mode, a few engaged with each other's diverging opinions in a relatively respectful agonistic fashion, and often the entries simply coexisted in cyberspace without any discernable explicit communicative link. But none of the contributions managed to penetrate the communication barrier between the institution's settled, objectifying cultural memory of genocide and the users more fluid, emergent and opinionated exchange reflecting more or less firmly held positions and prejudices. The communication strategy of the UsнmM makes perfect sense. Like their professional colleagues across the globe in the business of Holocaust memory, the managers at the USHMM are heavily dependent on government subsidies and private philanthropy. They have a lot to lose and nothing to gain by politicizing their activities, because negative press coverage would alienate sponsors, endanger their business model and jeopardize the value of their brands.

But the purposeful depolitization of genocide memory has important negative consequences. In light of the USH MM's actual communication patterns the mission of official Holocaust memory 'never again genocide' is misleading. The multifold activities of the harbingers of official memory reflect communicative aims and practices that are best summarized as 'never again Holocaust/

66 Butch Allen Seals on Ushmm's Facebook page, 26 August, 2016, https://www.facebook .com/holocaustmuseum/. Accessed 23 August, 2016.

67 Anna Bull and Hans Hansen, "On Agonistic Memory," Memory Studies 9/4 (2016), 390-404. 
genocide without memory. The overwhelming share of their investigative and communicative efforts are not geared towards identifying countries/groups at risk, assembling preventive expertise and actions and lobbying aggressively for early intervention - that would fit the motto 'never again' which represents a vital argument in justifying their sizeable budgets. Rather, the activities are fabulously well suited for preventing the kind of black hole of Holocaust memory that existed roughly between 1945 and $1975 .{ }^{68}$ Institutions such as USHMM will never again waste the memory opportunities and memory obligations that present themselves during and after genocide but they are not sure how to address the arduous task of shaping political will to action. This understandable reticence occurs at a most unfortunate moment when transhumans and their parents, representing a wide spectrum of different media biographies, need to learn how to congregate into viable we's and launch politically relevant memory cultures.

\section{YouTube, Twitter and Genocide Prevention Efforts in an Academic Bubble}

The Usнm m's leadership appears to be very aware of the disconnect between genocide memory and genocide prevention and dedicates some of its resources to engage politicians and academics in genocide prevention outreach. Unfortunately, these efforts do not seem to accomplish the desired results. The us нмм has, for example, recently enlarged and re-calibrated its Center for the Prevention of Genocide in order 'to make the prevention of genocide a core priority for leaders and academics around the world through its multi-pronged program of research, education, and public outreach. ${ }^{69} \mathrm{On} 19$ May, 2016 the new centre staged a high-profile one-day event in pursuit of these lofty goals which was ambitiously entitled Partners in Prevention: A Global Forum on Ending Genocide and featured an impressive line-up of politicians, policy experts, NGO

68 On the evolution of Holocaust culture see for instance Rebecca Jinks, Representing Genocide: The Holocaust as Paradigm? (London: Bloomsbury, 2016); and Wulf Kansteiner and Todd Presner, "Introduction: The Field of Holocaust Studies and the Emergence of Global Holocaust Culture," in Probing the Ethics of Holocaust Culture, edited by Claudio Fogu, Wulf Kansteiner and Todd Presner (Cambridge MA: Harvard University Press, 2016), 1-42.

69 "Museum Announces \$20 Million Gift to Name the Simon-Skjodt Center for the Prevention of Genocide," Usнмм, 19 February, 2015, https://www.ushmm.org/information/ press/press-releases/museum-announces-2o-million-gift-to-name-the-simon-skjodtcenter-for-the-pr. Accessed 22 October, 2016. 
leaders and academics. ${ }^{70}$ The guests spoke eloquently about the challenges of genocide prevention, for instance with regard to the warning-to-response-gap. In that context, they identified a number of strategies to be pursued further and studied more closely, including the need to work together with local elites in identifying and containing potentially particularly violent militias ('militia mapping'). Coverage of the event was widely shared through social media but appears to have triggered no substantive responses. As of 28 August, 2016, the YouTube-clip of the panel about 'Bridging the Warning-to-Response Gap' uploaded on 24 May counted 13 views. ${ }^{71}$ The enthusiastic tweets sent out during the event by Usнмм social media coordinator Kai Frazier ('Packed house for \#USH Mm's \#PreventGenocide forum' and 'I so enjoy working with these two. \#UsHmm's@NaomiKikoler \& @Qattouby of \#Syria discussing how to \#Prevent Genocide $^{72}$ ) also elicited no response.

The tweets inadvertently highlight a perfectly normal yet troublesome divide. For academics and assorted experts, discussions about genocides past and present provide a memory comfort zone ('I so enjoy working with these two'). Through meetings and connected outreach coverage they validate each other's work in an atmosphere of competitive respect and sombre performances attesting to their caring disposition and intellectual control of the subject matter. At the same time that they are crafting self-affirmative memory aesthetics they are often quite critical of other, popular strategies of genocide aesthetization. The lack of self-reflexivity is nicely illustrated by Holocaust research initiatives in the thriving and rapidly expanding transcultural terrain of the digital humanities. In 2014, after several years of path-breaking research, a team of scholars published a volume entitled Geographies of the Holocaust, marking the arrival of the spatial turn in Holocaust studies. ${ }^{73}$ With the help of relatively large quantitative data sets, they raised and answered intriguing questions about the ghettoization process, the mass murder of civilians in occupied Eastern Europe, the arrest of Jews in wartime Italy and the expansion of the ss camp system in general and Auschwitz in particular. But in their

70 "Partners in Prevention: A Global Forum on Ending Genocide," ushmm, https://www .ushmm.org/confront-genocide/speakers-and-events/all-speakers-and-events/partnersin-prevention-a-global-forum-on-ending-genocide. Accessed 22 October, 2016.

71 That number had increased to 14 by October 2016, usнmм, "Bridging the Warning-toResponse Gap," https://www.youtube.com/watch?v=iDNshd6yOns\&feature=youtu.be. Accessed 22 October, 2016.

72 Kai M. Frazier, Twitter post, 24 May, 2016, https://twitter.com/hashtag/preventgenocide. Accessed 22 October, 2016.

73 Anne Kelly Knowles, Tim Cole \& Alberto Giordano (eds.), Geographies of the Holocaust (Bloomington: Indiana UP, 2014). 
enthusiasm for the innovative methods of spatial analysis and geovisualization the authors and the publishers included in the volume a number of beautifully rendered artistic illustrations and condensations of their quantitative analyses that inadvertently channel Nazi visions of living space and geographical control. ${ }^{74}$ Put differently, the book, like so many publications in the field of Holocaust history and Holocaust studies, fails to address and acknowledge the profound sense of unease that, pace Saul Friedlander, ${ }^{75}$ should help us address the troubling parallels between the perpetrators' worldview and genocidal projects and our attempts to render them explicable and meaningful in history and memory. Considered from this perspective, the bit maps of digital humanities Holocaust scholarship are the selfies of the academic world and, as visual products in an ironic twist of analogue-digital remediation, perfectly compatible with a Nazi point of view of the camp system and deportation network. All this is not surprising. As to be expected, the digital humanities in general and scholarly Holocaust digital culture in particular primarily serve the purpose of providing new venues for the pursuit and display of transnational expert culture. There is no reason to assume that the use of digital technology in historical research would automatically inspire scholars to develop a more self-critical and politically ambitious relationship to the past.

\section{From Electronic to Digital Media Reception Studies?}

The study of Holocaust culture, including the present essay, has always channelled wide-ranging assumptions about the use of memory culture, assumptions shared by many qualitative analyses in the field of memory studies. Countless research projects advance on the reasonably sounding premise that the content and structure of the memory products under discussion correlate with the communication experiences surrounding those products. That assumption is problematic because we simply do not possess or have not extensively analysed reception data that would exhaustingly document

74 Claudio Fogu, “A 'Spatial Turn' in Holocaust Studies?” in Probing the Ethics of Holocaust Culture, edited by Claudio Fogu, Wulf Kansteiner and Todd Presner (Cambridge MA: Harvard University Press, 2016), 218-239; see also "Interview with Anne Knowles, Tim Cole, Alberto Giordano, and Paul Jaskot," in in Probing the Ethics of Holocaust Culture, edited by Claudio Fogu, Wulf Kansteiner and Todd Presner (Cambridge MA: Harvard University Press, 2016), 240-256.

75 Saul Friedländer, Years of Extermination: Nazi Germany and the Jews, 1939-1945 (New York: Harper Perennial, 2009). 
correlations between media content, media aesthetics and media use. Media archives contain a wealth of quantitative usage data but they reflect powerful commercial and political interests and often only provide rather imprecise insights into actual audience behaviour. ${ }^{76}$ Moreover, we have generally only been able to retain fragmentary qualitative reception data about electronic or digital media usage which causes serious problems for the historical studies of TV audiences. As a result of these gaps, there is a great deal of research on media effects ${ }^{77}$ but we still lack information about key audience segments, for instance of the audiences of such pervasive genres as televised sports, crime dramas $^{78}$ and historical programming. Consequently, there are good reasons to assume that indifference, ironic use, and simply unpredictable vectors of reception are systematically underreported in available audience research. With hindsight and a little remediative conceptual imagination it appears likely that the predominant reception models used to make sense of audiences in the era of film and television reveal a great deal of information about scholarly assumptions informing these models without having been able to bridge the gap between implicit and real audiences. In addition, the field of media reception studies has for a long time operated with outdated conceptual frameworks focusing first on national audiences and then on individual agency, but lacking, for instance, sophisticated concepts for the study of global media audiences. ${ }^{79}$

The limits of audience studies are all the more frustrating since Holocaust culture began with an undisputed feat of media reception studies. When the NBC TV series Holocaust was broadcast on us prime time in April 1978 to public acclaim, more than 30 countries followed suit and laid the foundation to the type of transnational Holocaust memory with which we are familiar today. In Germany, the decision to purchase and broadcast the series was widely discussed for months before the series hit the screen in January 1979. The unusual public deliberations about public TV scheduling decisions gave German media and media scholars plenty of advance warning. As a result, viewers experienced an unprecedented wave of contextualizing media coverage of the

76 Jerome Bourdon and Cecile Meadel (eds.), Television Audiences Across the World: Deconstructing the Ratings Machine (New York: Palgrave Macmillian, 2014).

77 See for example Patrick Rössler (ed.), The International Encyclopedia of Media Effects (Walden: Wiley, 2017).

78 Matt Briggs, Television, Audiences and Everyday Life (New York: Open University Press, 2010), 2.

79 Adrian Athique, Transnational Audiences: Media Reception on a Global Scale (Cambridge: Polity, 2016). 
TV event and media scholars had a chance to prepare a similarly unprecedented state-of-the-art reception analysis of the docu-drama whose possible effects on German audiences was a point of great curiosity at home and abroad.80 The research subsequently proved that the carefully scripted event had indeed a remarkable short-term and possibly also decisive long-term impact on German collective memories of the Nazi period. $50 \%$ of the West German adult population had seen at least one instalment of the series and more than 10,000 viewers wrote letters or called the station giving voice to intense feelings of shock and shame at the extent and systematicity of Nazi judeocide. ${ }^{81}$ At a time when successful prime time history fare generated on average a few hundred viewer responses, Holocaust set a stunning record that has no parallel in the history of German television.

Unfortunately, the path-breaking research strategies of 1979 remained an isolated effort. Media scholars interested in gauging the relevance of mass media programming for the development of collective memories have to content themselves with the type of reception data that public television networks generate as a matter of course and have generally no access to the archives of private networks. As a result, TV's important contributions to the task of public remembrance have to be guesstimated on the basis of quantitative ratings, a historically dwindling number of professional reviews, a handful of inconsistently selected and archived viewer responses and the occasional case study conducted by researchers in the networks or their academic peers. Under those circumstances memory scholars have a tough time reconstructing communication processes initiated and reflected by TV. More specifically, they are largely prevented from documenting multidirectional use of historical $\mathrm{TV}$ coverage and forced to resort to the kind of unsophisticated interpretation of mass media data often encountered in the field of memory studies. Time and again, the narrative worlds of extraordinary media events are taken to reflect dominant trends of collective remembrance without proper attention paid to television seriality and routines, complex transnational and multi-media interactions, as well as actual reception processes. ${ }^{82}$

8 Claus Wilke, "Die Fernsehserie 'Holocaust' als Medienereignis," Zeitgeschichte-online, March 2004, <http://www.zeitgeschichteonline.de/md=FSHolocaust-Wilke>.

81 Yitzhak Ahrens et al., Das Lehrstück "Holocaust:" Zur Wirkungsgeschichte eines Medienereignisses (Opladen: Westdeutscher Verlag, 1982).

82 Just as guilty as everybody else in this regard: Wulf Kansteiner, In Pursuit of German Television: History, Television, and Politics after Auschwitz (Athens, он: Ohio University Press, 2006). 
The fields of memory and media studies face familiar problems and might repeat old mistakes as they try to gauge the role of digital media in the development of 21st century historical imaginations without good empirical data. ${ }^{83} \mathrm{On}$ the one hand, fragmented digital memories are probably more dynamic and diverse than collective memories in the broadcasting era. On the other hand, digital culture offers many more opportunities for externalizing memories, for instance in social media settings, and, in principle, memory politics could therefore be studied more systematically than previously possible. But the age of television and the era of digital memory differ in another important respect. Good qualitative TV reception data did not exist in the 2oth century and had to be created at considerable expenses by researchers inside and outside the networks. In contrast, memory researchers now face a truly perverse situation of abundance and radical inaccessibility. Digital communication network providers collect and aggregate unbelievably extensive and sophisticated data about their costumers' media habits for the purpose of improving network efficiency and selling network access to advertisers and content providers. In principle, these data allows unprecedented insights in the generation of historical consciousness because multi-platform consumption of historical content and explicit generation of historical interpretation can be recorded in unprecedented depth and breadth. For the network providers, individual media biographies and crowd tastes and reflexes are open books and, if the providers were so inclined, easily captured by existing algorithms. But that treasure trough is off limits for academic researchers who are carefully shielded from the business secrets of the industry and tied to the rules of privacy laws which place strict limits on the way available data can be used for research purposes, for instant, as a result of the sound principle of informed consent. From a scholarly perspective, the transition from nationally framed public TV networks, which belatedly provided access to its extensive production and reception records, to powerful commercial corporations, which sell web access and content on a transnational scale, represents a tragic turn of events. For better or the worse, the scholarly utopia of being able to watch and reconstruct the process of historical consciousness formation in great detail and perhaps even in real time will never come to pass. In that sense, comprehensive reception analysis of narrative historical worlds, a term that might have been a misnomer from the get-go because it structurally underestimated consumers' interpretive agency, appears now less realistic than ever before. Nevertheless, exciting research opportunities abound with regard to the impact of interactive and immersive digital memory and artificial intelligence on our historical imaginations. Some

83 Michael Gray, Contemporary Debates in Holocaust Education (New York: Palgrave, 2014). 
social media, for instance Twitter, are relatively accessible for researcher trying to capture interactive historical culture in action. ${ }^{84}$ Moreover, with the help of fairly straightforward digital research techniques, for example web analytics, researchers can generate interesting insights into the use of online historical information even without access to proprietary information of network providers. ${ }^{85}$ Last but not least, there is always the option of informed consent, i.e., of cooperating with consumers, for instance by tracking their engagement with historical data on mobile devices or by observing their adventures in immersive simulative gaming environments. The collective memories of the future, including the memories of war and genocide, will be generated in thoroughly interactive, immersive, and counterfactual narrative worlds - even if it will still be difficult for researcher to observe that process, reconstruct it after the fact and really understand reception processes.

\section{Conclusion}

Holocaust culture was invented in the era of analogue media. It is a creature of photography, film, radio, television, architecture and conventional museum aesthetics and was fully developed before the rise of digital culture. When Schindler's List was released in 1993 and the Holocaust Memorial Museum in Washington D.c. opened its doors in the same year, personal mobile phones and PlayStation did not exist. Despite its long analogue history, the cosmopolitan Holocaust memory of the new millennium is synonymous with digital technology. On a few occasions, Holocaust culture has even produced pathbreaking digital advances as in the case of the Shoah Foundation's database of 53,000 survivor testimonies which are turned into superior research and teaching tools through highly innovative search engines. ${ }^{86}$ But the rigid interpretive frame and carefully moderated distribution systems of cosmopolitan Holocaust memory render it incompatible with central elements of our digitized everyday life. Official Holocaust memory is professionally managed for the purpose of safeguarding the mission and long-term interests of the respective memory institution. In its current format, official Holocaust culture

\footnotetext{
84 Katrin Weller et al., Twitter and Society (New York: Peter Lang, 2013).

85 Richard Rogers, Digital Methods (Cambridge, MA: MIT Press, 2013).

86 Todd Presner, "The Ethics of the Algorism: Close and Distant Listening to the Shoah Foundation Visual History Archive," in Probing the Ethics of Holocaust Culture, edited by Claudio Fogu, Wulf Kansteiner and Todd Presner (Cambridge MA: Harvard University Press, 2016), 175-202.
} 
therefore represents an antithesis to the nimble, decentralized exchanges of opinions driving social media communication. Moreover, with its fear of counterfactual historical representations linked to concerns about Holocaust denial intrinsic to the field, official Holocaust culture is a particular hostile environment for cutting-edge simulative and immersive virtual reality technologies. As a result, connective, emergent digital Holocaust memories exist in some social media contexts, but not in the institutional settings designed to teach Holocaust and genocide memory. Official Holocaust memory is thus poorly prepared to participate in meaningful ways in the exciting recalibration of virtual, real and embodied experiences set into motion by digital culture and especially AI technology. ${ }^{87}$ In the important memory arena of Holocaust culture, formalized, regimented standards for the deployment of digital technology have hitherto prevailed.

The International Holocaust Remembrance Alliance (IHRA), founded in Stockholm in 2000, has nicely summarized reservations about social media shared by many Holocaust educators and Holocaust memory managers. As the IHRA explicated in its 2014 guidelines for the use of social media in Holocaust education: 'Trends such as Holocaust denial, diminishment and trivialization are rampant on the Internet and using social media has the potential to introduce these topics to students and give them unwarranted prominence.' Moreover, 'social media is typically seen as platform for entertainment - the purview of pop culture, not learning and intellectual debate. ${ }^{88}$ It is not clear from the document to what extent the IHRA shares these reservations. In my view, the authors of the guidelines fail to point out that the online presence of Holocaust denial should not be equated with its popularity. There is a significant degree of Holocaust-denial-phobia in Holocaust culture, some of it instrumentalized for fund-raising purposes. The distanciation from Holocaust entertainment contains a similarly disingenuous element. All Holocaust and Ns-history learning sites, including Yad Vashem, Auschwitz, Buchenwald or the Usнмм have great, more or less intentionally crafted thanatouristic entertainment potential - otherwise they would not be as popular as they are.

The problems lie elsewhere and should be more clearly and honestly addressed. Cosmopolitan Holocaust memory and emergent digital Holocaust culture (to the degree that the latter exists) represent different, competing types

87 See the interesting historicization of virtual reality cultures in Melanie Chan, Virtual Reality: Representations in Contemporary Media (London: Bloomsbury, 2014).

88 "Using Social Media in Holocaust Education," International Holocaust Remembrance Alliance, April 2014, https://www.holocaustremembrance.com/media-room/stories/newsocial-media-guidelines. Accessed 22 October, 2016. 
of history edutainment with the emergent culture featuring a wider spectrum of narrative scripts and much more dynamic, at times unpredictable vectors of interpretive power than its well-established predecessor. Fast-paced and unscripted discussions about the politics of memory in social media, often driven by a rush to judgment, can result in powerful temporary consensus in support of official Holocaust culture. But social media also facilitate multi-directional, volatile confrontations about important problems of interpretation that defy cosmopolitan Holocaust culture. A case in point is the multi-voiced discussion about genocide, Islamophobia, and us war crimes spontaneously and collectively crafted in response to the UsHmm Facebook feed about Syria discussed above. These kinds of discussions have significant politicizing potential but are generally systematically sidestepped by risk-averse Holocaust memory institutions eager to avoid political exposure. These discussions highlight a central dilemma of cosmopolitan Holocaust culture: One cannot successfully pursue the political objective of genocide prevention while strenuously trying to avoid political risk-taking. Genocide prevention requires political courage and that is in short supply in cosmopolitan Holocaust memory.

For related reasons, official Holocaust memory keeps a careful distance from the captivating virtual environment of video game culture, observing somewhat helplessly from the sidelines the rise of a paradigm of popular entertainment that threatens its business model and allegedly also its ethical raison d'etre. Video games facilitate a new quality of absorbing, shared immersion in narrative cultural worlds, including realistically shaped historical worlds, based on rapid multi-sensory input, ludic pleasure and a significant degree of narrative and especially spatial control. It is now technologically completely realistic to recreate virtually Nazi society according to our (scholarly) ideas of how that society functioned. Or, to put a finer point to it, we can bring to virtual, interactive life our interpretations of the extreme social universe of Auschwitz and/ or any of the 42,500 other Nazi camps that covered the continent of Europe. ${ }^{89}$ The virtual camp scenario constitutes a central representational taboo of contemporary Holocaust culture. That taboo has a lot to do with taste, power and the history of Holocaust memory - and it represents perfectly legitimate concerns about the political and ethical purposes that could possibly be served by breathing a second, virtual life into the hell that was Auschwitz. Most likely, these concerns do not represent any absolute limits of representation but reflect the limits of our present-day didactic-ludic imagination. We simply do

89 Eric Lichtblau, "The Holocaust Just Got More Shocking”, New York Times, 1 March, 2013, accessed 23 October, 2016, http://www.nytimes.com/2013/o3/o3/sunday-review/the-holocaust-just-got-more-shocking.html? src = me\&ref $=$ general\&_r $=1$. 
not yet know what lines of historical interpretation and corresponding game rules a virtual Auschwitz should embody so that the gamers immersed in that truthfully recreated and therefore extremely violent world would emerge from the game with a self-reflexive democratic historical consciousness. How can the act of releasing into the world algorithms for a virtual Auschwitz support a human rights agenda of inter-cultural respect and non-violence? However, putting those legitimate concerns into writing immediately holds up a critical mirror to our familiar, comfortable cosmopolitan Holocaust experiences. How did we ever assume that a historical culture that incessantly and compulsively circles around the dark holes of torture, mass death and extreme moral depravity serves those very same objectives? Does spelling out the dark holes in virtual detail really makes all that much of an ethical difference?

While we might not yet be able to design a good Auschwitz game, that problem does not apply to other didactically valuable, ludically viable, and historically realistic Nazi game ideas. What would be wrong with designing the virtual world of Nazi-occupied Poland, France, the Netherlands or Denmark, having players assume the perspectives of Jews caught in the maelstrom, seeking out the few existing loopholes to safety and learning in the process that the vast majority of Jews were increasingly faced with choiceless choices and no hope for rescue? Such a game should be at least as capable of inducing empathy with the victims as the Holocaust movies of past decades which are probably becoming increasingly ineffective as a didactic tool for younger audiences steeped in digital culture. And why stop there? Why not work on a spin-off Aleppo 2016 game which follows the trial and tribulations of Syrian refugees on their way to Europe as the try to escape from Assad, rebel troops, Isis and Russian air strikes and try to overcome global disinterest and prejudice in very much the same way as German Jewry in the summer of 1939. If scripted intelligently such an Aleppo-game would go a long way to expose the depravity of Europe's political elite of 2016 as they tried to shed their Geneva Convention, UN Human Rights Charter and EU Convention on Human Rights obligations. ${ }^{90}$ In fact, it is difficult to imagine any video game about the topic that would be in such poor taste as the 'game' that said politicians have been playing with the

9o In fact, a successful and ethically valuable game that follows the suggested trajectory already exists. That war of mine released by a Polish developer in 2014 lets players experience the struggle for survival of a group of civilians in a fictional besieged Eastern European city. Loosely based on the 1992-96 siege of Sarajewo the game goes a long way in creating empathy with war victims, see Clark, Justin. 2014. "Counting Body like Sheep to the Rhythm of the War Drum," Gamespot, November 17, 2014. Accessed 25January, 2017, https://www.gamespot.com/reviews/this-war-of-mine-review/1900-6415963/. 
lives of millions of refugees whom they have denigrated and sought to contain in overcrowded camps outside the EU.

Simulative interactive narrative worlds exploring past and present crimes against humanity could also offer new, decidedly self-critical perspectives on perpetrator and bystander biographies. Digital game formats seem to be very well suited to have players experience in their own virtual life the slippery slope of the conformism, prejudice and fanaticism that precede genocide. In this fashion, genocide gaming could assume a self-critical quality and teach players, reflecting on their own virtual ethical failures and virtual crimes, how to recognize and counteract the early warning signs of radicalization and indifference. Since gaming with its extraordinary immersive potential offers the ambivalent (and for 'analoguers' very troublesome) experience of being simultaneously inside and outside a given simulative world, a Holocaust game could help overcome a didactic impasse that cosmopolitan Holocaust culture has thus far never been able to solve: it could complicate and possibly undermine the troublesome structural parallels between the passive bystanders of the Holocaust of the 1940 and the relative passive consumers of official Holocaust culture of the last four decades, a culture that has taught consumers the virtues of remembering the victims (never again genocide $\mathrm{w} / \mathrm{h}$ memory) but provided little meaningful guidance in self-critically engaging with legacies of perpetration and preventing large scale victimization (never again genocide). Given the high stakes involved, the first realistic, fully immersive, interactive and simulative Holocaust game should be developed at the centre of our Holocaust culture, for instance, through a collaboration between the Shoah Foundation, ushm M, Yad Vashem, the Gedenkstättennetzwerk, the Museum of Tolerance and other interested parties. The task is too important and too expensive and has too great a didactic potential to be left exclusively to commercial enterprises or freelance outfits.

In my view, the examples of digital Holocaust culture cited above do not yet demonstrate conclusively that today's gamers, social media users and their technological devices represent a fundamentally different memory species than their electronic forbearers. At the same time, the examples indicate that the users of digital culture put a premium on becoming the narrators of their own memories and escaping the relatively narrow thematic confines of established Holocaust memory, a multi-directional desire they might share with generations of film and television consumers who simply did not have similar cultural agency.

While we are still busy trying to figure out the dynamics of mediatized human collective memories, post-human collective memory is already thriving, for example in the form of self-reflexive AI robotics. Robots are intelligent to 
the extent that they engage in self-reflexive learning, i.e., a kind of social memory leading to a degree of unpredictability and autonomy. AI learning processes and collective memories are modelled after human learning and collective memory but feature new patterns of retention and forgetting that turn AI robots into different memory agents than humans. Ironically, that makes them particularly suitable objects for media reception analysis while their interactions with humans also break the mould of anything that can be reasonably grasped with the methods of reception studies. Hence, a crucial task in the field of robotics consists of developing effective guidelines for roboethics and robot ethics preventing humans from irresponsibly using AI robotics and imbuing robots with robust circuits of self-critical memory in the hope that they will get better at this task than humans ever were. ${ }^{91}$ The response to that challenge will decisively influence the quality of post-human social relations, the future of self-critical memory, and, way down on the list of possible concerns, the need to develop new concepts of memory studies.

\section{References}

“ADL Statement on Quentin Tarrantino's 'Inglourious Basterds'” archive adl.org, 18 August, 2009. Accessed 21 October, 2016. http://archive.adl.org/presrele/ holna_52/5585_52.html\#.V852dBRoU6U.

Ahrens, Yitzhak et al., Das Lehrstück "Holocaust:" Zur Wirkungsgeschichte eines Medienereignisses. Opladen: Westdeutscher Verlag, 1982.

Alexander, Jeffrey. "The Social Construction of Moral Universals," in Remembering the Holocaust: A Debate, edited by Jeffrey Alexander et al. Oxford: Oxford University Press, 2009. 3-101.

Alexander, Jeffrey. Cultural Trauma: A Social Theory. Cambridge: Polity, 2012.

Athique, Adrian. Transnational Audiences: Media Reception on a Global Scale. Cambridge: Polity, 2016.

Bodnar, John. The "Good War" in American Memory. Baltimore: Johns Hopkins University Press, 2010.

Bolden, Tonya. How to Build a Museum: Smithsonian's National Museum of African American History and Culture. New York: Viking, 2016.

Bourdon, Jerome and Cecile Meadel, eds., Television Audiences Across the World:Deconstructing the Ratings Machine. New York: Palgrave Macmillian, 2014.

91 On roboethics and robot ethics see Gianmarco Veruggio, Fiorella Operto, George Bekey, "Roboethics: Social and Ethical Implications," Bruno Siciliano and Oussam Khatib (eds.), Handbook of Robotics (Berlin: Springer, 2016), 2135-2160. 
"Bridging the Warning-to-Response Gap." Accessed 22 October, 2016. https://www.youtube.com/watch?v=iDNshd6yOns\&feature=youtu.be.

Briggs, Matt. Television, Audiences and Everyday Life. New York: Open University Press, 2010.

Bull, Anna and Hans Hansen. “On Agonistic Memory," Memory Studies 9/4 (2016), 390-404.

LaCapra, Dominick. Writing History, Writing Trauma Baltimore: Johns Hopkins University Press, 2014.

De Cesari, Chiara and Ann Rigney. "Introduction." In Transnational Memory: Circulation, Articulation, Scales, edited by Chiara De Cesari and Rigney. Berlin: DeGryuter, 2014. 1-25.

Chan, Melanie. Virtual Reality: Representations in Contemporary Media. London: Bloomsbury, 2014.

Chapman, Adam. Digital Games as History: How Videogames Represent the Past and Offer Access to Historical Practice. New York: Routledge, 2016.

Chare, Nicholas and Dominic Williams. Matters of Testimony: Interpreting the Scrolls at Auschwitz. New York: Berghahn, 2016.

Crecente, Brian. "Anti-Defamation League Slams 'Fun' Holocaust Video Game as Horrific and Inappropriate." Kotaku, 11 December, 2010. Accessed 21 October, 2016. http://kotaku.com/5712163/anti-defamation-league-slams-fun-holocaust-video -game-as-horrific-and-inappropriate.

DarkWolfLetsPlay. “08:46/9/11 Terrorist Attack Oculus Rift Game.” YouTube, 19 October, 2015. Accessed 21 October, 2016. https://www.youtube.com/watch?v=vd2_j8dsOsM.

Dassanowsky, Robert, ed., Quentin Tarantino's Inglourious Basterds: A Manipulation of Metacinema. New York: Continuum, 2012.

Day, Eric. "Why We Don't Have a Holocaust Video Game and Why We Desperately Need One." overmental.com, 5 May, 2014. http://overmental.com/content/why-wedont-have-a-holocaust-video-game-and-why-we-desperately-need-one-1303.

“Die Internetseite 'Kinder im Ghetto:' Kommentare für Lehrer." Yad Vashem, http:// ghetto.galim.org.il/ger/about/lessons.html. Accessed 22 October, 2016.

van Dijck, José. The Culture of Connectivity: A Critical History of Social Media. Oxford: Oxford University Press, 2013.

“Don't Stand By: Holocaust Memorial Day 2016: What You Can Do," http://hmd.org. uk/sites/default/files/HMD_files/dont_stand_by_-_final.pdf. Accessed 22 October, 2016.

“Don't Stand By: Holocaust Memorial Day 2016: Lesson Activity: British Heroes of the Holocaust," http://hmd.org.uk/sites/default/files/british_heroes_of_the_holocaust _resource.pdf. Accessed 22 October, 2016.

Dörner, Ralf, Stefan Göbel, Wolfgang Effelsberg and Josef Wiemers, eds., Serious Games: Foundations, Concepts and Practice. Cham: Springer, 2016. 
Ernst, Wolfgang. Digital Memory and the Archive. Minneapolis: University of Minnesota, 2013.

Eyerman, Ron. Cultural Trauma: Slavery and the Formation of African American Identity. Cambridge: Cambridge University Press, 2001.

Fearn, Andy, "НмDт Eteach: A new interactive, multimedia resource to support educators in teaching effectively about the Holocaust and subsequent genocides," (paper presented at the BAHS Conference 2016, UCL, 20 July, 2016).

Fogu, Claudio. “A 'Spatial Turn' in Holocaust Studies?” In Probing the Ethics of Holocaust Culture, edited by Claudio Fogu, Wulf Kansteiner and Todd Presner. Cambridge MA: Harvard University Press, 2016. 218-239.

"For Educators," Holocaust Memorial Day Trust, http://hmd.org.uk/content/for-educators. Accessed 22 October, 2016.

Frazier, Kai M., Twitter post, 24 May, 2016, https://twitter.com/hashtag/preventgenocide. Accessed 22 October, 2016.

Frei, Norbert. "Zum erneuten Dienstjubiläum der 'Achtundsechziger': Generation Sündenstolz," Neue Züricher Zeitung, 3 August, 2008.

Friedländer, Saul. Years of Extermination: Nazi Germany and the Jews, 1939-1945. New York: Harper Perennial, 2009.

Garde-Hansen, Joanne, Andrew Hoskins and Anna Reading, eds., Save As ... Digital Memory. Basingstoke: Palgrave Macmillan, 2009.

Gold, Riva. "Designers Pull Plug on Auschwitz Death Camp RevoltVideo Game." Haartz. com, 26 December, 2010. Accessed 21 October, 2016. http://www.haaretz.com/ jewish/designers-pull-plug-on-auschwitz-death-camp-revolt-video-game-1.333022.

Goldberg, Amos and Haim Hazan, eds., Marking Evil: Holocaust Memory in the Global Age. New York: Berghahn, 2015.

Gray, Michael. Contemporary Debates in Holocaust Education. New York: Palgrave, 2014. Hansen-Glucklich, Jennifer. Holocaust Memory Reframed: Museums and the Challenges of Representation. New Brunswick: Rutgers University Press, 2014.

Harrigan, Pat, Matthew Kirschenbaum and James Dunnigan, eds., Zones of Control: Perspectives on Wargaming. Cambridge, MA: MIT Press, 2016.

Hayton, Jeff. "Beyond Good and Evil: Nazis and the Supernatural in Video Games." In Revisiting the "Nazi Occult:" Histories, Realities, Legacies, edited by Monica Black and Eric Kurlander. Rochester: Camden House: 2015. 248-269.

Hilberg, Raul. The Politics of Memory: The Journey of a Holocaust Historian. Ivan Dee, 1996.

“HMD 2016: Lesson Plan: Didn't Stand By," http://hmd.org.uk/education/hmd-2016 -lesson-plan-didnt-stand. Accessed 22 October, 2016.

Hoskins, Andrew. "Digital Network Memory," in Mediation, Remediation and the Dynamic of Cultural Memory, edited by Astrid Erll and Ann Rigney. Berlin: De Gruyter, 2009. 91-106. 
Hoskins, Andrew. “The Right to be Forgotten in Post-Scarcity," in , The Ethics of Memory in a Digital Age: Interrogating the Right to be forgotten, edited by Alessia Ghezzi et al. New York: PalgraveMacmillian, 2014. 50-64.

Hoskins, Andrew. "The Restless Past: An Introduction to Digital Memory and Media," in Digital Memory Studies: Media Pasts in Transition, edited by Andrew Hoskins. New York: Routledge, forthcoming.

Hume, Janice. Popular Memory and the American Revolution. New York: Routledge, 2014. Huntemann, Nina and Matthew Payne, eds., Joystick Soldiers: The Politics of Play in Military Video Games. New York: Routledge, 2010.

"Imagination Is The Only Escape." Indiegogo.com. Accessed 21 October, 2016. https:// www.indiegogo.com/projects/imagination-is-the-only-escape\#/.

"International School for Holocaust Studies: Learning Environments." Yad Vashem. http://www.yadvashem.org/yv/en/education/learning_environments/index.asp. Accessed 22 October, 2016.

"Interview with Anne Knowles, Tim Cole, Alberto Giordano, and Paul Jaskot." In Probing the Ethics, edited by Claudio Fogu, Wulf Kansteiner and Todd Presner. Cambridge MA: Harvard University Press. 240-256.

“IWitness Video Challenge: Top Videos by Groups - 2016." University of Southern California. http://iwitness.usc.edu/SFI/IWitnessChallenge/Winners.aspx?y=2016 Accessed 22 October, 2016.

Jinks, Rebecca. Representing Genocide: The Holocaust as Paradigm? London: Bloomsbury, 2016.

Justin, Clark. "Counting Body like Sheep to the Rhythm of the War Drum," Gamespot, November 17, 2014. Accessed 25 January, 2017. https://www.gamespot.com/reviews/ this-war-of-mine-review/190o-6415963/.

Kaiser, Wolfram. "Limits of Cultural Engineering: Actors and Narratives in the European Parliament's House of European History Project," Journal of Common Market Studies 55/3 (2017), 518-534.

Kansteiner, Wulf. In Pursuit of German Television: History, Television, and Politics after Auschwitz. Athens, он: Ohio University Press, 2006.

Kansteiner, Wulf. "Macht, Authentizität und die Verlockungen der Normalität: Aufstieg und Abschied der NS-Zeitzeugen in den Geschichtsdokumentationen des ZDF." In Die Geburt der Zeitzeugen nach 1945, edited by Martin Sabrow and Norbert Frei. Göttingen: Wallstein, 2013. 320-353.

Kansteiner, Wulf and Todd Presner. "Introduction: The Field of Holocaust Studies and the Emergence of Global Holocaust Culture," in Probing the Ethics of Holocaust Culture, edited by Claudio Fogu, Wulf Kansteiner and Todd Presner. Cambridge MA: Harvard University Press, 2016. 1-42.

Kappell, Matthew and Andrew Elliott, eds., Playing with the Past: Digital Games and the Simulation of History. New York: Bloomsbury, 2014. 
Kempshall, Chris. The First World War in Computer Games. New York: Palgrave Macmillian, 2014.

Kline, Daniel, ed., Digital Gaming Re-imagines the Middle Ages. London: Routledge 2014. Knowles, Anne, Tim Cole and Alberto Giordano, eds., Geographies of the Holocaust. Bloomington: Indiana UP, 2014.

"KZ Manager." Wikipedia, last updated 21 October, 2016. Accessed 21 October, 2016. https://de.wikipedia.org/wiki/KZ_Manager.

Lentin, Ronit. Co-Memory and Melancholia: Israelis Memorialising the Palestinian Nakba. Oxford: Oxford University Press, 2010.

Levy, Daniel and Nathan Sznaider. The Holocaust and Memory in the Global Age. Philadelphia: Temple University Press, 2006.

Lichtblau, Eric. “The Holocaust Just Got More Shocking”, New York Times, 1 March, 2013. Accessed 23 October, 2016, http://www.nytimes.com/2013/o3/o3/sunday-review/ the-holocaust-just-got-more-shocking.html?src=me\&ref=general\&_r=1.

"Life Stories," http://hmd.org.uk/resources/life-stories. Accessed 22 October, 2016.

Loh, Christian, Yanyan Sheng and Dirk Ilfenthaler. "Serious Games Analytics: Theoretical Framework." in Serious Games Analytics: Methodologies for Performance Measurement, Assessment, and Improvement, edited by Christian Loh, Yanyan Sheng and Dirk Ifenthaler. Cham: Springer, 2015 . 3-29.

Luke K. "WWII Games:Where is the Holocaust." Critical Gamer, 17 January, 2011. Accessed 21 October, 2016. http://www.criticalgamer.co.uk/2011/o1/17/wwii-games-where-is -the-holocaust/.

McWherto, Michael. "Concentration Camp Game Was Meant To Be Fun." Kotaku, 10 December, 2010. Accessed 21 October, 2016. http://kotaku.com/5711317/concentration -camp-game-was-meant-to-be-fun.

Meyers, Oren, Eyal Zandberg and Motti Neiger, eds., Communicating Awe:Media Memory and Holocaust Commemoration. New York: Palgrave Macmillian, 2014.

Moses, Dirk. "Conceptual Blockages and Definitional Dilemmas in the 'Racial Century:' Genocides of Indigenous Peoples and the Genocide." In Colonialism and Genocide, edited by Dirk Moses and Dan Stone. Routledge: New York, 2007. 148-180.

"Museum Announces \$20 Million Gift to Name the Simon-Skjodt Center for the Prevention of Genocide." Usнmм, 19 February, 2015. Accessed 22 October, 2016. https:// www.ushmm.org/information/press/press-releases/museum-announces-20 -million-gift-to-name-the-simon-skjodt-center-for-the-pr.

"New Dimension in Testimony - USC ICT and sfi Classroom Concept." 8 February, 2013. Accessed 24 October, 2016. http://www.youtube.com/watch?v=AnF63otCiEk.

Niven, Bill. "German Victimhood Discourse in Comparative Perspective," in Dynamics of Memory and Identity in Contemporary Europe, edited by Eric Langenbacher, Bill Niven and Ruth Wittlinger. New York: Berghahn, 2012. 180-194. 
Ochman, Ewa. Post-Communist Poland: Contested Pasts and Future Identities. New York: Routledge, 2013.

Olick, Jeffrey. The Sins of the Fathers: Germany, Memory, Method. Chicago: University of Chicago Press, 2016.

Parikka, Jussi. A Geology of Media. Minneapolis: University of Minnesota Press, 2015.

"Partners in Prevention: A Global Forum on Ending Genocide." us Hm M. Accessed 22 October, 2016. https://www.ushmm.org/confront-genocide/speakers-and-events/ all-speakers-and-events/partners-in-prevention-a-global-forum-on-ending -genocide.

Plygon. "The New Order shows you the horror of concentration camps from the first person.” YouTube, 19 May, 2014. Accessed 21 October, 2016. https://www.youtube .com/watch?v=DbQ3H6lEWDE.

Pogacar, Martin. Media Archeologies, Micro-Archives and Story-Telling: Re-Presencing the Past. Basingstoke: Palgrave Macmillan, 2016.

Presner, Todd. "The Ethics of the Algorism: Close and Distant Listening to the Shoah Foundation Visual History Archive." In Probing the Ethics of Holocaust Culture, edited by Claudio Fogu, Wulf Kansteiner and Todd Presner. Cambridge MA: Harvard University Press, 2016. 175-202.

Ritterfeld, Ute, Michael Cody, Peter Vorderer, eds., Serious Games: Mechanisms and Effects. New York: Routledge, 2009.

Robertson, Adi. "The virtual reality $9 / 11$ experience is bad, but not for the reasons you'd expect." The Verge, 30 October, 2015. Accessed 21 October, 2016. http://www .theverge.com/2015/10/30/964279o/virtual-reality-9-11-experience-empathy.

Rogers, Richard. Digital Methods. Cambridge, MA: MIT Press, 2013.

Rothberg, Michael. Multidirectional Memory: Remembering the Holocaust in the Age of Decolonization. Stanford: Stanford UP, 2009.

Rothe, Ann. Popular Trauma Culture: Selling the Pain of Others. New Brunswick, 2011.

Rüsen, Jörn. Historik: Theorie der Geschichtswissenschaft. Cologne: Böhlau, 2013.

Rutten, Ellen, Julie Fedor and Vera Zvereva, eds., Memory, Conflict and New Media: Web Wars in Post-Socialist States. New York: Routledge, 2013.

Rössler, Patrick, ed., The International Encyclopedia of Media Effects. Walden: Wiley, 2017.

Shandler, Jeffrey. While America Watches: Televising the Holocaust. Oxford: Oxford University Press, 1999.

Sierp, Aline. History, Memory, and Trans-European Identity: Unifying Divisions. New York: Routledge, 2014.

"Slave Trade Video Game Edited After Backlash." Huffington post, 3 September, 2015. Accessed 21 October, 2015. http://www.huffingtonpost.com/entry/slave-trade-game -edited-following-backlash_us_55e8489be4bob7a9633bdc73. 
"Sonderkommando Revolt Wolfenstein 3D mod." Last updated 13 December, 2010, http://www.moddb.com/mods/sonderkommando-revolt. Accessed 21 October, 2016.

Stauber, Roni, ed., Collaboration with the Nazis: Public Discourse after the Holocaust. New York: Routledge, 2011.

Stuart, Sophia. "How Natural Language Tech, Holograms Are Preserving Holocaust Testimony." pcmag.com, 8 April, 2016. Accessed 24 October, 2016. http://www.pcmag .com/article/343452/how-natural-language-tech-holograms-are-preservingholocaus.

Takashi, Dean. "Brenda Romero's Train board game will make you ponder." venturebeat. com, 11 May, 2013. Accessed 21 October, 2016. http://venturebeat.com/2013/05/11/ brenda-romero-train-board-game-holocaust/.

“Teaching Resources." Holocaust Educational Trust, http://www.het.org.uk/teachingpack. Accessed 22 October, 2016.

“Teacher Resources: Educating Hearts and Minds." Museum of Tolerance, http://www .museumoftolerance.com/site/c.tmL6KfNVLtH/b.5052463/k.AE91/Teacher_Resources.htm. Accessed 22 October, 2016.

"The International School for Holocaust Studies: Education Materials." Yad Vashem http://www.yadvashem.org/yv/en/education/index.asp. Accessed 22 October, 2016.

"UN Commission of Inquiry on Syria: ISIS is committing genocide against the Yazidis." United Nations Human Rights Office of the High Commissioner, 16 June, 2016. Accessed 22 October, 2016. http://www.ohchr.org/en/NewsEvents/Pages/DisplayNews .aspx?NewsID=20113\&LangID=E.

"UN: Yezidi 'genocide has occurred and is ongoing'." Rudaw, 16 June, 2016. Accessed 22 October, 2016. http://rudaw.net/english/middleeast/16o62016.

Unterman, Phoebe. Through Eva's Eyes. Kansas City: Landmark, 2009.

"Using Social Media in Holocaust Education." International Holocaust Remembrance Alliance, April 2014. Accessed 22 October, 2016. https://www.holocaustremembrance.com/media-room/stories/new-social-media-guidelines.

Usнмм's Facebook page, https://www.facebook.com/holocaustmuseum/. Accessed 23 August, 2016.

Veruggio, Gianmarco, Fiorella Operto and George Bekey, "Roboethics: Social and Ethical Implications." In Handbook of Robotics, edited by Bruno Siciliano and Oussam Khatib. Berlin: Springer, 2016. 2135-216o.

Waddell, Kaveh. "A Video Game That Lets You Torture Iraqi Prisoners." theatlantic.com, 1 August, 2016. Accessed 21 October, 2016. http://www.theatlantic.com/technology/ archive/2016/o8/a-video-game-that-lets-you-torture-iraqi-prisoners/493379/.

Weller, Katrin et al. Twitter and Society. New York: Peter Lang, 2013. 
Wilke, Claus. "Die Fernsehserie 'Holocaust' als Medienereignis," Zeitgeschichte-online, March 2004, http://www.zeitgeschichteonline.de/md=FSHolocaust-Wilke.

Winnerling, Tobias and Florian Kerschbaumer, eds., Early Modernity and Video Games. Newcastle: Cambridge Scholars, 2014.

Worcman, Karen and Joanne Garde-Hansen. Social Memory Technology: Theory, Practice, Action. New York: Routledge, 2016.

Yahil, Leni. The Holocaust. New York: Oxford UP, 1990.

Zertal, Idith. Israel's Holocaust and the Politics of Nationhood. Cambridge: Cambridge University Press, 2005. 